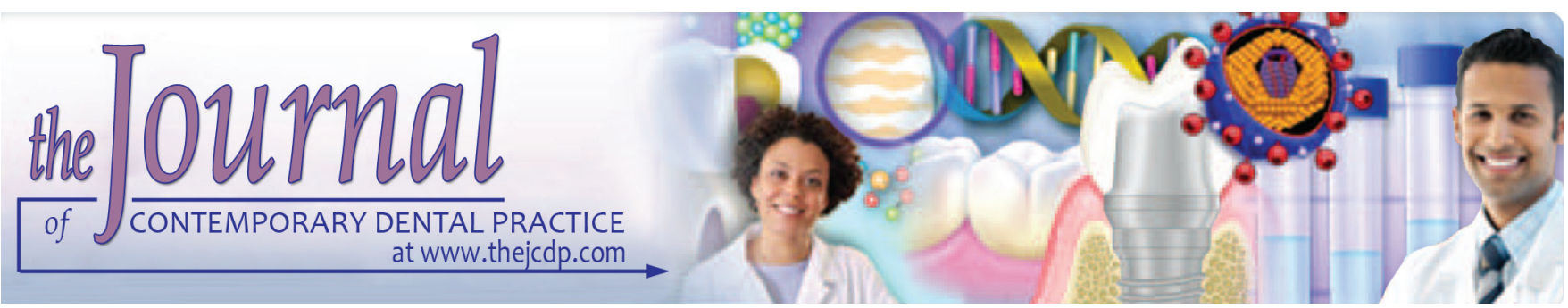

\title{
Molecular Detection of Porphyromonas gingivalis in Chronic Periodontitis Patients
}

\author{
${ }^{1}$ Pavan G Kulkarni, ${ }^{2}$ Suchitra Gosavi, ${ }^{3}$ Praveen B Haricharan, ${ }^{4}$ Suryakanth Malgikar, ${ }^{5}$ Durga P Mudrakola \\ ${ }^{6}$ Neeraja Turagam, ${ }^{7}$ Kranti KR Ealla
}

\section{ABSTRACT}

Aim: In the current study, Porphyromonas gingivalis was identified in chronic periodontitis patients and healthy subjects by polymerase chain reaction (PCR) and its presence correlated with the severity of clinical periodontal parameters.

Materials and methods: Subgingival plaque samples were collected with sterile curette and subjected to deoxyribonucleic acid (DNA) extraction and subsequent PCR for detection of $P$. gingivalis.

Results: Porphyromonas gingivalis was detected in $60 \%$ of patients of group II (pocket depth up to $5 \mathrm{~mm}$ ), and in $93.33 \%$ of patients of group III (pocket depth more than $5 \mathrm{~mm}$ ). One periodontally healthy subject in group I (probing depth $\leq 3 \mathrm{~mm}$ ) showed the presence of $P$. gingivalis.

Conclusion: Detection frequency of bacterium increased significantly with increase in probing pocket depth (PPD), loss of attachment (LOA), and gingival index (GI).

Clinical significance: Porphyromonas gingivalis is strongly associated with chronic periodontitis and its detection frequency positively correlates with the severity of periodontal destruction.

Keywords: Periodontal disease, Polymerase chain reaction, Porphyromonas gingivalis, Putative periodontal pathogens.

\footnotetext{
${ }^{1}$ Department of Oral and Maxillofacial Pathology, Kamineni Institute of Dental Sciences, Hyderabad, Telangana, India

2Department of Oral and Maxillofacial Pathology, Government Dental College \& Hospital, Nagpur, Maharashtra, India

3,5,6 Faculty of Dentistry, AIMST University, Jalan-Semeling Bedong, Malaysia

${ }^{4}$ Department of Periodontics, Kamineni Institute of Dental Sciences, Hyderabad, Telangana, India

${ }^{7}$ Department of Oral and Maxillofacial Pathology, MNR Dental College and Hospital, Hyderabad, Telangana, India

Corresponding Author: Kranti KR Ealla, Department of Oral and Maxillofacial Pathology, MNR Dental College and Hospital Hyderabad, Telangana, India, Phone: +919849409070, e-mail: drekkr@yahoo.co.in
}

How to cite this article: Kulkarni PG, Gosavi S, Haricharan PB, Malgikar S, Mudrakola DP, Turagam N, Ealla KKR. Molecular Detection of Porphyromonas gingivalis in Chronic Periodontitis Patients. J Contemp Dent Pract 2018;19(8):992-996.

\section{Source of support: $\mathrm{Ni}$}

Conflict of interest: None

\section{INTRODUCTION}

Periodontitis is a significant global health concern and is probably the most common chronic infectious disease of humans. Chronic periodontitis is considered to be a site-specific disease. The clinical signs of chronic periodontitis-inflammation, pocket formation, attachment loss and bone loss-are believed to be caused by the direct, site-specific effects of subgingival plaque accumulation. As a result of this local effect, pocketing, attachment loss, and bone loss may occur on one surface of a tooth, while other surfaces maintain normal attachment levels. ${ }^{1}$

The bacteria associated with periodontal disease have been studied since the advent of the science of microbiology. Leeuwenhoek ${ }^{2}$ gave the first detailed description of subgingival plaque and revealed considerable diversity of bacterial plaque. It has been estimated that more than 700 bacterial species can be identified within the subgingival plaque. ${ }^{3}$ Possibly, 10 to 30 species may play a more critical role in the pathogenesis of periodontal disease. ${ }^{4} \mathrm{~A}$ marked qualitative and quantitative difference between periodontally healthy and periodontitis subjects has been demonstrated. ${ }^{5}$ The predominating microorganisms isolated from the teeth and gingival sulcus of periodontally healthy individuals include mainly Gram-positive bacteria, facultative anaerobic bacteria, and rarely Gramnegative anaerobic rods. The Gram-negative anaerobic bacteria, on the contrary, are found to be predominant in the subgingival microflora with increasing severity 
of periodontal disease. ${ }^{6}$ Among these Gram-negative bacteria, P. gingivalis, Tannerella forsythia, and Treponema denticola have been designated as the red complex. These red complex species are significantly predominant in the periodontal pocket and associated with periodontal disease progression. Porphyromonas gingivalis is one of the main bacterial pathogens involved in the initiation and progression of periodontitis. It has been strongly implicated in the etiology of chronic periodontitis. ${ }^{7}$ It is a Gram-negative, obligatory anaerobic, nonmotile, asaccharolytic, and black-pigmented coccobacillus. ${ }^{8}$ Detecting the presence of major periodontal pathogens, such as P. gingivalis can indicate future risk of the disease, the level of aggression, and type of treatment required. A variety of methods have been developed and applied for identification and isolation of such bacteria. Bacterial culture is frequently regarded as the "gold standard." However, culture-based techniques suffer the limitation that they are time-consuming and laborious, and the sensitivity of culture methods is low. This is due to the extremely slow growth or very specific growth requirements of some oral pathogens. Several alternative methods have been developed for the detection of such bacteria, such as immunoassays, DNA probe assays, and PCR assays. ${ }^{9}$ The PCR has a higher sensitivity and specificity as compared with bacterial culture in detection of such bacteria.

In recent years, there has been great interest in PCRbased tests which use the bacterial small subunit $16 \mathrm{~S}$ ribosomal ribonucleic acid (rRNA) [16S recombinant DNA (rDNA)] for the detection of bacterial pathogens. Molecular analysis based on PCR of 16S rRNA (16S rDNA) gene is revolutionizing the study of the composition of the subgingival microflora by revealing the true extent of the bacterial communities present, free of the biases of culture. ${ }^{10}$ Thus, the present study aims at detecting $P$. gingivalis in subjects with chronic periodontitis exhibiting different levels of destruction using PCR-based assay and evaluating its correlation with clinical periodontal parameters.

\section{MATERIALS AND METHODS}

The present study was aimed to compare the detection frequency of $P$. gingivalis in chronic periodontitis patients with periodontally healthy subjects using PCR and also correlate its presence with the severity of clinical periodontal parameters assess PPD, clinical attachment level (CAL), and GI.

This cross-sectional study was carried out at single center in collaboration with the National Environmental Engineering Research Institute, Nagpur, India. The sample size of 40 human subjects comprising of both sexes was selected from the outpatient section. All the subjects included in the study signed an informed consent. The subjects were divided based on the periodontal status into periodontally healthy individuals, chronic periodontitis with PPD $<5 \mathrm{~mm}$, and chronic periodontitis with PPD $>5 \mathrm{~mm}$.

Group I: Periodontally healthy subjects $(\mathrm{n}=10)$

Group II: Patients having chronic periodontitis with probing depth $\leq 5 \mathrm{~mm}(\mathrm{n}=15)$

Group III: Patients having chronic periodontitis with probing depth $>5 \mathrm{~mm}(\mathrm{n}=15)$

The criteria for selection of periodontally healthy subjects were:

- Probing depth $\leq 3 \mathrm{~mm}$

- GI score $\leq 1$

- No signs of inflammation or mild inflammation

- Absence of bleeding after probing

The criteria for diagnosing periodontitis were:

- Probing depth $\geq 3 \mathrm{~mm}$

- GI score $\geq 2$

- Presence of inflammation

- Presence of bleeding after probing

\section{Exclusion Criteria}

- Subjects who had undergone periodontal treatment and had taken any antibiotics in the past 6 months.

- Subjects with the history of smoking or use tobacco in any form.

- All subjects with history of known systemic diseases.

\section{SCREENING AND EXAMINATIONS}

A total of 65 patients were screened out of which 40 patients (sample size of the study) in the age group of 25 to 55 years ( 17 males and 23 females) were enrolled in this cross-sectional study. The following clinical parameters, such as GI, ${ }^{11}$ gingival bleeding index, ${ }^{12}$ PPD, and CAL were recorded. The PPD and CALs were measured using UNC-15 graduated periodontal probe.

\section{SAMPLE COLLECTION AND STORAGE}

The sampling site was isolated using cotton rolls and supragingival plaque was removed with the help of sterile cotton. The subgingival plaque was then collected using sterile Gracey curette and suspended in $50 \mu \mathrm{L}$ of Tris- $\mathrm{HCl}$ buffer. These subgingival plaque samples were then immediately incubated at $50^{\circ} \mathrm{C}$ for 10 minutes and then stored at $-20^{\circ} \mathrm{C}$ (Cryo Scientific) till further processing. All the plaque samples were subjected to molecular analysis which was carried out at research institute.

\section{DEOXYRIBONUCLEIC ACID EXTRACTION AND ANALYSIS}

A volume of $50 \mu \mathrm{L}$ of Tris- $\mathrm{HCl}$ buffer containing plaque sample was incubated at $65^{\circ} \mathrm{C}$ for 15 minutes. 
Samples were centrifuged at 10,000 rpm for 5 minutes and supernatant was discarded. The washed cells were then suspended in $25 \mu \mathrm{L}$ of $0.5 \mathrm{~N} \mathrm{NaOH}$ solution. Care was taken to prevent the formation of any air bubbles for efficient lysis of cell wall and release of DNA. The suspension was incubated at room temperature for 30 minutes. This was followed by addition of $25 \mu \mathrm{L}$ of $1 \mathrm{M}$ Tris ( $\mathrm{pH}$ 7.5) for neutralization and the solution was mixed. Final volume was made by adding $450 \mu \mathrm{L}$ of sterile distilled water and an even mixing was brought about by vortex mixing.

\section{PCR for Detection of $P$. gingivalis (16S rDNA)}

All PCR reactions were carried out in $50 \mu \mathrm{L}$ reaction volume. The reaction mixture was prepared in a PCR tube. Primers used were $^{13}:$ P1 (Forward): 5'AAG CAG CTT GCC ATA CTG CG 3', P2 (Backward): 5'ACT GTT AGC AAC TAC CGA TGT 3'.

The PCR program included an initial denaturation step at $94^{\circ} \mathrm{C}$ for 5 minutes, followed by 35 cycles of denaturation at $94^{\circ} \mathrm{C}$ for 1 minute, primer annealing at $50^{\circ} \mathrm{C}$ for 1 minute and extension at $72^{\circ} \mathrm{C}$ for 1.5 minutes, and then final extension step at $72^{\circ} \mathrm{C}$ for 7 minutes in Thermal Cycler. The expected $404 \mathrm{bp}$ amplicon was analyzed on a $1.5 \%$ agarose gel under ultraviolet (UV) transillumination and photographic image was taken.

\section{AGAROSE GEL ELECTROPHORESIS}

The horizontal gel electrophoresis systems of standard dimensions from GIBCO-BRL were used in the experiments. The aqueous DNA samples to be loaded were mixed with this loading dye in a 5:1 ratio respectively, and subjected to agarose gel electrophoresis with a standard $1 \mathrm{~kb}$ ladder. For making the DNA visible, after completion of electrophoresis, the gel was stained in an aqueous solution of $0.5 \mathrm{mg} / \mathrm{mL}$ ethidium bromide. The DNA samples were visualized under UV light transilluminator. The presence or absence and the relative size of the DNA fragment were estimated based on comparison with the standard $1 \mathrm{~kb}$ ladder. The expected product lengths were 127 base pairs (bp) for P. gingivalis (Fig. 1).

\section{Statistical Analysis}

The data were collected, tabulated, and analyzed by Statistical Package for the Social Sciences version $10.0^{\complement}$ software. Fisher's exact test was applied to test the significance of difference between the groups for the presence of $P$. gingivalis. Spearman's rank correlation was used to determine if a statistically significant difference existed between the clinical periodontal parameters like probing depth, LOA, and GI with the presence of $P$. gingivalis. If $\mathrm{p} \leq 0.05$, then it was significant.

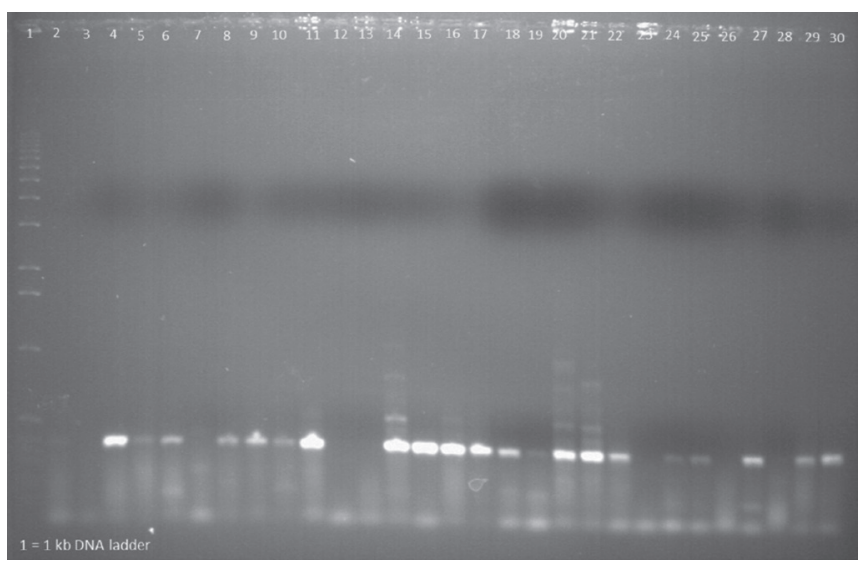

Fig. 1: Detection of $P$. gingivalis DNA using $2 \%$ agarose gel electrophoresis. Lane 1 is the standard $1 \mathrm{~kb}$ ladder. Lanes 4, 5, 6, $8,9,10,11,14-22,24,25,27,29$, and 30 show positive staining for $P$. gingivalis (around 127 bp size)

\section{RESULTS}

The present study was carried out on 40 subjects, distributed into three groups. Group I consisted of 10 periodontally healthy controls, group II consisted of 15 chronic periodontitis patients with probing depth $\leq 5 \mathrm{~mm}$, and group III consisted of 15 chronic periodontitis patients with probing depth $>5 \mathrm{~mm}$. The mean age of subjects from group I was $29.4 \pm 3.80$ years with a range of 25 to 36 years. Patients in group II showed a mean age of 40.60 \pm 5.27 years with a range of 33 to 52 years. Patients from group III exhibited a mean age of $45.66 \pm 5.08$ years and a range of 36 to 53 years.

The gender-wise distribution of subjects showed that in groups I and II, 40\% subjects were males and 60\% were females, and $46.67 \%$ males and $53.33 \%$ females in group III. There was no significant difference in genderwise distribution of subjects between the groups.

Porphyromonas gingivalis was detected in 1 (10.00\%) subject from group I, 9 (60.00\%) subjects from group II, and $14(93.33 \%)$ subjects from group III. Fisher's exact test showed a significant difference between groups I, II, and III for the presence of $P$. gingivalis ( $\mathrm{p}$-value $=0.00002)$ (Table 1).

Statistically significant positive correlation was noted between probing depth, LOA and GI, and the presence of $P$. gingivalis ( $\mathrm{p}$-value $=0.0000)($ Table 2$)$.

Table 1: Detection frequency of $P$. gingivalis in three groups (Fisher's exact test)

\begin{tabular}{ll}
\hline Groups & Presence of $P$. gingivalis \\
\hline I & $01(10.0 \%)$ \\
II & $09(60.0 \%)$ \\
III & $14(93.33 \%)$ \\
Fisher's exact test & p-value $=0.00002$ \\
\hline
\end{tabular}


Table 2: Association between clinical periodontal parameters with presence of $P$. gingivalis (Spearman rank correlation)

\begin{tabular}{lllll}
\hline $\begin{array}{l}\text { Clinical } \\
\text { parameter }\end{array}$ & $\begin{array}{l}\text { Presence of } \\
\text { P. gingivalis }\end{array}$ & $r$-value & $p$-value & Result \\
\hline PPD & Presence & +0.693 & 0.0000 & Sig \\
LOA & Presence & +0.691 & 0.0000 & Sig \\
GI score & Presence & +0.560 & 0.0000 & Sig \\
\hline
\end{tabular}

PPD: Probing pocket depth; LOA: Loss of attachment; GI score: Gingival index score

\section{DISCUSSION}

Periodontitis is a multifactorial disease that is associated with loss of the supporting tissues (i.e., periodontal ligament and alveolar bone) around the tooth. ${ }^{14}$ It is widely accepted that the disease occurs as a result of subgingival plaque with specific bacteria, particularly Gram-negative anaerobes. ${ }^{15}$ The use of clinical parameters in sample site selection, particularly PPD measurements, is likely to enhance the chance of detecting pathogenic bacteria. Similarly, sample site selection based on the presence of bleeding upon probing is likely to increase the chance of detecting putative pathogens. ${ }^{16}$

Several diagnostic methods can be used to detect bacterial species that have been identified as periodontal pathogens, including $P$. gingivalis. These methods include bacterial culture, enzymatic assays, immunoassays, nucleic acid probes, checkerboard DNA-DNA hybridization and PCR. ${ }^{17}$

The culture method is considered the gold standard (reference method) while determining the utility of a new microbial diagnostics in periodontics. Culture methods rely on the detection of viable organisms and require that samples are immediately processed upon acquisition in order to maximize bacterial survival. The method can presumptively identify periodontal pathogens only in conjunction with biochemical tests, such as sugar fermentation and analysis of bacterial enzymatic activities. ${ }^{15}$

Nucleic acid-based methods, such as use of DNA probes and PCR, are quicker and more consistent than anaerobic cultivation. These are exclusively used in the microbiological diagnosis of subgingival plaque samples of patients with progressive forms of periodontitis.

The present investigation found an increase in the prevalence of $P$. gingivalis with an increasing PPD. Porphyromonas gingivalis is a Gram-negative oral anaerobe that is involved in the pathogenesis of periodontitis and is a member of more than 500 bacterial species that live in the oral cavity. ${ }^{18}$ It is a black-pigmented bacterium which produces a myriad of virulence factors that causes wide destruction to periodontal tissues either directly or indirectly by modulating the host inflammatory response. ${ }^{19}$

Klein et $\mathrm{al}^{20}$ found the bacterium in $90 \%$ of patients with deeper pockets $>5 \mathrm{~mm}$ and $40 \%$ of patients with shallower pockets (up to $5 \mathrm{~mm}$ ), which is in agreement with the present study. Socransky et $\mathrm{al}^{21}$ also compared the microflora of periodontal pockets with different pocket depths and found a higher prevalence of $P$. gingivalis in deep pockets than in shallow pockets. In this study, a positive correlation between detection of $P$. gingivalis and increasing LOA was noted. These results are in accordance with the findings of Slots, ${ }^{22}$ and Takeuchi et al. ${ }^{23}$ Slots, ${ }^{22}$ while studying the association between the posttreatment periodontal disease activity and $P$. gingivalis, showed a strong positive association of presence of $P$. gingivalis with loss of periodontal attachment.

Christenson et $\mathrm{a}^{24}$ found that the odds ratio demonstrating P. gingivalis was 2.4 times greater $(\mathrm{p}<0.005)$ if the site had CAL $\geq 4 \mathrm{~mm}$. Takeuchi et $\mathrm{al}^{23}$ demonstrated that tendency for detection frequency of $P$. gingivalis correlated with CAL and the percentage of $P$. gingivalis positive sites increased with the increasing LOA in chronic periodontitis patients, indicating that $P$. gingivalis might be associated with the severity of periodontitis. Klein et $\mathrm{al}^{20}$ found an association between presence of $P$. gingivalis and LOA and suggested that sample site selection should be based on loss of CAL.

Atsushi ${ }^{25}$ showed that $P$. gingivalis detection had close relation with GI and it is adhered to the diseased gingiva. These results of the present study are in accordance with Takeuchi et al. ${ }^{23}$ However, $\mathrm{Chen}^{26}$ could not find any statistically significant correlation between the presence of $P$. gingivalis and GI.

In the present study, only one periodontally healthy subject $(10.00 \%)$ tested positive for $P$. gingivalis which is in agreement with Loesche ${ }^{27}$ who suggested that healthy subjects either do not exhibit $P$. gingivalis or exhibit the bacterium in low numbers. Similar results were demonstrated by Takeuchi ${ }^{23}$ and Missailidis. ${ }^{28}$ These findings are slightly lower than that of Griffen ${ }^{29}$ and Amano ${ }^{30}$ who showed the presence of $P$. gingivalis in 40 and $36.8 \%$ of healthy subjects respectively. Faghri ${ }^{31}$ detected $P$. gingivalis in $25 \%$ of healthy subjects. This difference in prevalence of $P$. gingivalis in healthy subjects may be attributed to smaller sample size of the control group in our study. The present study highlights the association of $P$. gingivalis with chronic periodontitis; however, more extensive studies are advocated to correlate the periodontopathogens in systemic diseases as well as to evaluate the pathogenic and nonpathogenic strains of $P$. gingivalis.

\section{CONCLUSION}

Porphyromonas gingivalis is strongly associated with chronic periodontitis and its detection frequency positively correlates with the severity of periodontal destruction. Further studies should be done for analysis of genomic data, which makes it possible to explore the 
patterns of gene expression of these bacteria and thus better define the pathogenesis of the disease. Integration of this information provides the basis for proactive approaches for prevention, diagnosis, and treatment of periodontal disease.

\section{REFERENCES}

1. Newman MG, Takei H, Klokkevold PR, Carranza FA. Carranza's clinical periodontology. Elsevier Health Sciences; $2011 \mathrm{Feb} 14$.

2. Leeuwenhoek A van. Arcana nature, Delphis Bartavorum, 1965, Reprinted in facsimile, Brussels, Culture et civilization 1966 cited from Carranza's Clinical Periodontology. 9th ed. Philadelphia: Saunders; 2003. p. 5.

3. Moore WE, Moore LV. The bacteria of periodontal diseases. Periodontology 20001994 Jun;5(1):66-77.

4. Socransky SS, Haffajee AD. Evidence of bacterial etiology: a historical perspective. Periodontology 20001994 Jun;5(1):7-25.

5. Socransky SS, Haffajee AD, Cugini MA, Smith C, Kent RL. Microbial complexes in subgingival plaque. J Clin Periodontol 1998 Feb;25(2):134-144.

6. Slots J, Rams TE. New views on periodontal microbiota in special patient categories. J Clin Periodontol 1991 Jul;18(6): 411-420.

7. Lamont RJ, Jenkinson HF. Subgingival colonization by Porphyromonas gingivalis. Oral Microbiol Immunol 2000 Dec;15(6):341-349.

8. Haffajee AD, Socransky SS. Microbial etiological agents of destructive periodontal diseases. Periodontology 20001994 Jun;5(1):78-111.

9. Boutaga K, van Winkelhoff AJ, Vandenbroucke-Grauls CM, Savelkoul PH. Comparison of real-time PCR and culture for detection of Porphyromonas gingivalis in subgingival plaque samples. J Clin Microbiol 2003 Nov;41(11):4950-4954.

10. De Lillo A, Booth V, Kyriacou L, Weightman AJ, Wade WG. Culture-independent identification of periodontitis-associated Porphyromonas and Tannerella populations by targeted molecular analysis. J Clin Microbiol 2004 Dec;42(12):5523-5527.

11. Löe H, Silness J. Periodontal disease in pregnancy I. Prevalence and severity. Acta Odontologica Scandinavica 1963 Jan;21(6):533-551.

12. Carter HG, Barnes GP. The gingival bleeding index. J Periodontol 1974 Nov;45(11):801-805.

13. Wu Y, Yan J, Chen LL, Gu Z. Association between infection of different strains of Porphyromonas gingivalis and Actinobacillus actinomycetemcomitans in subgingival plaque and clinical parameters in chronic periodontitis. J Zhejiang Univ Sci B 2007 Feb;8:121-131.

14. Malgikar S, Reddy SH, Sagar SV, Satyanarayana D, Reddy GV, Josephin JJ. Clinical effects of photodynamic and low-level laser therapies as an adjunct to scaling and root planing of chronic periodontitis: a split-mouth randomized controlled clinical trial. Indian J Dent Res 2016 Mar-Apr;27(2):121-126.

15. Riggio MP, Macfarlane TW, Mackenzie D, Lennon A, Smith AJ, Kinane D. Comparison of polymerase chain reaction and cultural methods for detection of Actinobacillus actinomycetemcomitans and Porphyromonas gingivalis in subgingival plaque samples. J Periodont Res 1996 Oct;31(7):496-501.
16. Christersson LA, Fransson CL, Dunford RG, Zambon JJ. Subgingival distribution of periodontal pathogenic microorganisms in adult periodontitis. J Periodontol 1992 May;63(5): 418-425.

17. Loomer PM. Microbiological diagnostic testing in the treatment of periodontal diseases. Periodontol 2000 2004;34:49-56.

18. Mysak J, Podzimek S, Sommerova P, Lyuya-Mi Y, Bartova J, Janatova T, Prochazkova J, Duskova J. Porphyromonas gingivalis: major periodontopathic pathogen overview. J Immunol Res 2014;2014:476068.

19. How KY, Song KP, Chan KG. Porphyromonas gingivalis: an overview of periodontopathic pathogen below the gum line. Front Microbiol 2016 Feb 9;7:53.

20. Klein MI, Goncalves RB. Detection of Tannerella forsythensis (Bacteroides forsythus) and Porphyromonas gingivalis by Polymerase chain reaction in subjects with different periodontal status. J Periodontol 2003 Jun;74(6):798-802.

21. Socransky SS, Haffajee AD, Cugini MA, Smith C, Kent Jr. RL. Microbial complexes in subgingival plaque. J Clin Periodontol 1998 Feb;25(2):134-144.

22. Slots J, Emrich LJ, Genco RJ, Rosling BJ. Relationship between some subgingival bacteria and periodontal pocket depth and gain or loss of periodontal attachment after treatment of adult periodontitis. J Clin Periodontol 1985 Aug;12(7):540-552.

23. Takeuchi $Y$, Umeda M, Sakamoto M, Benno Y, Huang Y, Ishikawa I. Treponema socranskii, Treponema denticola, and Porphyromonas gingivalis are associated with severity of periodontal tissue destruction. J Periodontol 2001 Oct;72(10):1354-1363.

24. Christersson LA, Fransson CL, Dunford RG, Zambon JJ. Subgingival distribution of periodontal pathogenic microorganisms in adult periodontitis. J Periodontol 1992 May;63(5): 418-425.

25. Atsushi F. Relationships between periodontal pathogens and clinical parameters in patients with adult periodontitis. Detection from diseased gingiva and subgingival plaque by PCR methods. J Japanese Assoc Periodontol 1998;40:389-399.

26. Chen LL, Wu YM, Yan J, Sun WL, Sun YZ, Ojeius D. Association between coinfection of Porphyromonas gingivalis, Actinobacillus actinomycetemcomitans and Treponema denticola and periodontal destruction in chronic periodontitis. Chin Med J (Engl) 2005 Jun;118(11):915-921.

27. Loesche WJ. DNA probe and enzyme analysis in periodontal diagnostics. J Periodontol 1992 Dec;63(12 Suppl):1102-1109.

28. Missailidis CG, Umeda JE, Ota Tsuzuki C, Anzai D, Mayer MPA. Distribution of fimA genotypes of Porphyromonas gingivalis in subjects with various periodontal conditions. Oral Microbiol Immunol 2004 Aug;19(4):224-229.

29. Griffen AL, Becker MR, Lyons SR, Moeschberger ML, Leys EJ. Prevalence of Porphyromonas gingivalis and periodontal health status. J Clin Microbiol 1998 Nov;36(11):3239-3242.

30. Amano A, Kuboniwa M, Nakagawa I, Akiyama S, Morisaki I, Hamada S. Prevalence of specific genotypes of Porphyromonas gingivalis fimA and periodontal health status. J Dent Res 2000 Sep;79(9):1664-1668.

31. Faghri J, Moghim S, Abed AM, Rezaei F, Chalabi M. Prevalence of Porphyromonas gingivalis and Bacteroides forsythus in chronic periodontitis by multiplex PCR. Pakistan J Biol Sci 2007 Nov;10(22):4123-4127. 